Southern Illinois University Carbondale

OpenSIUC

Publications

Department of Plant Biology

$12-1995$

\title{
The Relationship between the Soil Seed Bank and Above-Ground Vegetation of a Coastal Barrier Island
}

Paul B. Looney

David J. Gibson

Southern Illinois University Carbondale, dgibson@plant.siu.edu

Follow this and additional works at: http://opensiuc.lib.siu.edu/pb_pubs

Published in Journal of Vegetation Science Vol. 6, No. 6 (1995): 825-836.

\section{Recommended Citation}

Looney, Paul B. and Gibson, David J. "The Relationship between the Soil Seed Bank and Above-Ground Vegetation of a Coastal Barrier Island." (Dec 1995).

This Article is brought to you for free and open access by the Department of Plant Biology at OpenSIUC. It has been accepted for inclusion in

Publications by an authorized administrator of OpenSIUC. For more information, please contact opensiuc@lib.siu.edu. 


\title{
The relationship between the soil seed bank and above-ground vegetation of a coastal barrier island
}

\author{
Looney, Paul B. ${ }^{1,2}$ \& Gibson, David J..$^{1^{*}}$ \\ ${ }^{1}$ Institute for Coastal \& Estuarine Research, University of West Florida, Pensacola, FL 32514-5751 USA; \\ ${ }^{2}$ Present address: Ecology \& Environment, Inc, 316 S. Baylen Street, Suite 540, Pensacola, FL 32501 USA; \\ Tel. +1 904435 8925; Fax +1 904435 9135; *Corresponding Author; Present address: Department of Plant Biology, \\ Southern Illinois University at Carbondale, Carbondale, IL 62901-6509 USA; \\ Tel. +1 618453 3231; Fax +1 618453 3441; E-mail DGIBSON@PLANT.SIU.EDU
}

\begin{abstract}
The germinable soil seed bank is described from a coastal barrier island off the northwest coast of Florida, USA. Soil samples collected from seven vegetation types, recently deposited dredge spoil and unvegetated areas in autumn 1990 and spring 1991 were placed out in greenhouse trays. 110 taxa germinated from the samples with the largest number (41) being $\mathrm{C}_{3}$ perennial dicots. The largest number of taxa germinated from dry (57) and wet (54) swales, the fewest (one species: Heterotheca subaxillaris) from strand. Similarity of seed bank densities to above-ground species cover was low (Jaccard's Index $=0.36$ ), not different between vegetation types, but higher in the autumn than in the following spring. Compositional gradients in the seed bank and above-ground vegetation determined using DCA ordination were highly correlated and related to distance from mean high water, and plot elevation. At the landscape scale, the seed bank provided an equally clear delineation of vegetation types to that based upon the above-ground vegetation. The seed bank of low disturbance, late-succession vegetation types (wooded dunes, swales, marshes) was well developed (high species richness, emergent density, and percentage annual species) with the exception that the large-seeded woody species (i.e. Quercus spp.) were absent from the wooded dune seed bank. By contrast, a poorly developed and transient seed bank occurred in more frequently disturbed (extensive sand movement, salt spray), early successional dredge spoil, unvegetated areas and strand. These contrasts support a general pattern of increasing seed bank development and a persistent rather than transient seed bank with decreasing disturbance frequency, increasing time since disturbance and successional maturity.
\end{abstract}

Keywords: DCA; Disturbance; Dune; Florida; Succession.

Nomenclature: Looney et al. (1993).

\section{Introduction}

Studies from many plant communities have shown the importance of the soil seed bank to ecosystem development following disturbance (Keddy et al. 1989).
Whether a seed bank is either transient or persistent (Thompson \& Grime 1979) has been proposed to be related to successional age and disturbance regime (Thompson 1978; Pierce \& Cowling 1991a). However, the nature of this relationship is equivocal (Donelan \& Thompson 1980; Pierce \& Cowling 1991a), mainly because few studies compare the seed bank of a diversity of habitats (although see Thompson \& Grime 1979; Partridge 1989). Most seed bank studies consider a single habitat or plant community, e.g., grassland, forest, wetland (e.g. van der Valk \& Davis 1978; Roach 1983; Matlack \& Good 1990; Warr et al. 1994).

It has been proposed that sand dune systems do not have a persistent soil seed bank because the shifting and dynamic nature of the substrate does not favor a significant carry over of seeds from one season to the next (Planisek \& Pippen 1984; Ehrenfeld 1990). Studies of the seed biology of several annual and biennial species have confirmed this supposition (Mack 1976; Watkinson 1978; Boorman \& Fuller 1984). However, Pemadasa \& Lovell (1975) and Zhang \& Maun (1994) showed that buried seeds of sand dune species can remain viable for more than two years thus providing the potential to form a persistent seed bank. Pierce \& Cowling (1991a) showed that frequently disturbed dune grasslands possessed a seed bank of comparative density to less-frequently disturbed woody thickets in South African coastal dunes. These studies suggest that coastal dune systems may contain extensive germinable soil seed banks that would be important in regenerating plant communities following disturbance.

In this study we describe the quantitative relationship between the germinable soil seed bank of a coastal dune ecosystem and the above-ground flora. The site is a coastal barrier island and hence offered the opportunity to sample several plant communities across a narrow, but clear environmental gradient (Gibson \& Looney 1992). The vegetation types present range from frequently disturbed coastal strand, through a series of 
dune types, to temporally stable yet contrasting wooded dunes and saline lagoonal marshes. These vegetation types offered a contrast in successional age, landscape position, and disturbance frequency. The objectives of the study were to determine (1) the extent to which coastal dune plant communities possess a germinable soil seed bank, (2) the similarity between the composition of the soil seed bank and the above-ground flora, and (3) how differences in seed bank composition from different vegetation types are related to community stability and relative successional age.

\section{Methods}

\section{Study sites}

The study site was the easternmost $11 \mathrm{~km}$ of the Gulf Islands National Seashore (GINS) portion of Perdido Key, a barrier island off the northwest coast of Florida, USA $\left(87^{\circ} 24^{\prime} \mathrm{W}, 30^{\circ} 18^{\prime} \mathrm{N}\right)$. The barrier island consists of Uniola paniculata dunes, wet and dry swales, wooded dunes, back slopes and Juncus roemerianus tidal saltmarshes on the lagoon side. Except for a ranger station and the ruins of a World War II artillery battery, the area is undeveloped. A series of vegetation types is aligned across the island from the Gulf to Lagoon side reflecting a disturbance (sand movement and salt spray) gradient (Gibson \& Looney 1992, 1994 see Fig. 4) and a successional chronosequence as the island rolls over migrating landward (Dolan \& Lins 1987; Stone \& Morgan 1993). Frequent storms and hurricanes are a part of the natural disturbance regime affecting vegetation development (Cousens 1988; Stone \& Salmon 1988; Gibson et al. 1995).

The easternmost $8 \mathrm{~km}$ of the GINS was nourished with approximately 5.4 million $\mathrm{m}^{3}$ of dredge spoil from the nearby Pensacola Pass in late 1990 to counteract shoreline erosion and dispose of beach quality sand dredged to maintain the pass for marine navigation (Work et al. 1991). The dredge spoil was placed immediately below the old mean high water (MHW) for an average width of $122 \mathrm{~m}$, at an elevation of approximately $1.7 \mathrm{~m}$. Except a few sand fences near the old MHW, this 'new beach' was not managed, and vegetation colonized naturally (Gibson \& Looney 1994).

The climate of the area is warm subtropical with mean July-August temperatures of $28.5^{\circ} \mathrm{C}$ and mean January temperatures of $11.0^{\circ} \mathrm{C}$ (Palik \& Kunneke 1984; Stalter 1993). There are 300 frost-free days and average rainfall is $1597 \mathrm{~mm}$, with more than $50 \%$ of the precipitation occurring during convectional thunderstorms that occur in the summer rainy season (May 20 through September 20). The driest months are usually
October and November. A second rainy season associated with cold fronts occurs from late December until mid-March. The hurricane season runs from June to November, with the greatest number of storms occurring from August to October.

\section{Data collection}

As part of a long-term vegetation monitoring program (Gibson \& Looney 1992, 1994; Looney \& Gibson 1993), 224 permanent $5 \mathrm{~m} \times 2 \mathrm{~m}$ sample plots were established along 13 cross-island transects on Perdido Key in 1989. Plots were at 12-m intervals along each transect for the first $120 \mathrm{~m}$ above MHW and every $24 \mathrm{~m}$ thereafter, crossing the island from the Gulf side to the water's edge on the northern lagoon side. An additional 70 permanent plots were established across the dredge spoil in autumn 1990 along extensions of the crossisland transects below the old MHW.

Two soil samples of approximately $600 \mathrm{ml}$ each were collected using a hand trowel from the top $5 \mathrm{~cm}$ of the soil in 65 of the permanent plots in both autumn 1990 (December) and spring 1991 (June). Sample plots were chosen based upon their classification from autumn 1989 and represented five samples from each of seven vegetation types - i.e. strand, back dunes, wooded dunes, other dune types (established, developing, disturbed and low), dry swales, wet swales, and marsh (Gibson \& Looney 1992). Some plots were reassigned within this classification using TWINSPAN and Discriminant Analysis (Gibson \& Ely 1994) when the plots were reclassified based upon characteristics of the aboveground vegetation at the time of soil sample collection in autumn 1990. The reclassification altered the number of plots sampled per vegetation type to range from two to seven (Table 1). Seven samples were also collected from unvegetated areas and 11 samples were collected below old MHW on the dredge spoil. After collection, samples were stored in the lab just above the freezing point until placed out in a greenhouse five days later. Each of the two samples from each field plot was divided into two equal subsamples by volume giving four subsamples. The subsamples were spread evenly in a 1-2 cm layer over $4-5 \mathrm{~cm}$ of vermiculite or perlite in a $14 \times 17.8 \times 6 \mathrm{~cm}$ plastic tray. Pairs of subsamples were placed, in their trays, into larger trays and placed randomly on greenhouse benches. The larger trays were rearranged within the greenhouse periodically. These trays were maintained under greenhouse conditions of natural light and temperatures from $18-42^{\circ} \mathrm{C}$. The soils were watered regularly and fertilized with $0.14 \mathrm{~g} / 1$ 'PETERS' 20:20:20 NPK (Grace-Sierra Horticultural Products, Milpita, California) three times in the first two months. Control trays of autoclaved beach sand $\left(120^{\circ} \mathrm{C}\right.$ 
for $54 \mathrm{~min}$ at 103 kilopascals) were interspersed in the greenhouse to detect potential contamination from seeds being dispersed throughout the greenhouse. No seedlings were noted in any of the control trays.

Germinating seedlings were monitored daily for the first month of the study and weekly for the next three months and every four weeks after that as numbers germinating diminished. Seedlings of all species were counted and removed as identified over the course of the next nine months. The soils were stirred at four-six months to expose ungerminated seeds following cessation of the initial flush of germinants. Voucher specimens of seedlings of each species at different stages of growth have been deposited in the Perdido Key collection of the herbarium of the University of West Florida.

It is likely that counts of germinating seedlings in samples under greenhouse conditions overestimates the functional contribution of the seed bank to seedling recruitment (Peart 1989). However, in large-scale surveys such as in this study it is not practical to make a complete enumeration of soil-stored seed followed by seed viability tests. The direct germination procedure used here is efficacious, time efficient, and gives ecologically meaningful estimates of the seed bank (Gross 1990; Rothrock et al. 1993). This technique is particularly suitable for the detection of persistent seed banks in which component seeds are more than one year old (Thompson \& Grime 1979). By contrast, transient seeds banks are those in which none of the seed persists in a viable condition for more than one year (Thompson \& Grime 1979). Although not exhaustive, our methodology involving samples from the autumn and following spring allows a general distinction between these two types of seed bank to be made.

Cover abundance of above-ground plants in the field was estimated in the seed bank sample plots in autumn 1990 and spring 1991 according to the Daubenmire scale (Daubenmire 1959) within 25 permanently located $0.1-\mathrm{m}^{2}$ quadrats. The quadrats used were randomly located the first time the plots were sampled in 1989 and 1990 surveys (Gibson \& Looney 1992). Initial data analysis calculated the mean species cover per permanent plot from mid-points of the Daubenmire cover values.

\section{Data analysis}

The total number of seedlings germinating per tray was summed for each sample plot (four trays per plot) and retained for analysis. Seedling totals are expressed as field density per $\mathrm{m}^{2}$ and are summarized by life form. Differences in numbers of germinating seedlings of each species per vegetation type and sample date (autumn 1990 or spring 1991) were not tested statistically because of the non-normal nature of the data, and the high frequency of zero seedlings per vegetation type for each species (Warr et al. 1994).

Fisher's exact test (StatMost, Ver 2.5, Data Most Corp., Salt Lake City, UT) was used to test the significance of the proportion of above-ground vegetation indicator species (from Gibson \& Looney 1992) that had their highest seedling density in the vegetation type for which they were designated an indicator species.

The similarity of the seed bank flora to the aboveground flora was compared by calculating Jaccard's similarity coefficient (Anderberg 1973) between paired sample plots in which both seed bank and above-ground species presence/absence data were available $(n=54)$. Jaccard's similarity coefficient was calculated as the number of species present both in the seed bank and above-ground vegetation divided by the total number of species in the seed bank and above-ground on a per plot basis. Coefficient values range from zero, no species in common, to one, identical set of species. Compared with several other similar indices, Jaccard's coefficient is robust and unbiased even at small sample sizes (Goodall 1973; Ludwig \& Reynolds 1988). The relationship between seed bank/above-ground similarities and transect number (a measure of possible east-west gradients), and plot number (a measure of distance from MHW) were tested using Spearman rank correlations. The relationship between the season of sampling, vegetation type and seed bank/above-ground similarities was investigated using ANOVA in SAS (Anon. 1990a, b). Plots from the dredge spoil and unvegetated areas were excluded from this analysis because there were no plots in which species occurred both in the seed bank and above-ground.

The quantitative relationship between sample plots was assessed using Detrended Correspondence Analysis (DCA; Hill \& Gauch 1980) in ter Braak's CANOCO program (ter Braak 1988), an indirect ordination procedure in which sample plots are arranged along ordination axes based upon between-plot similarities in species composition. 87 samples from the autumn 1990 and spring 1991 seed bank study were ordinated using this procedure. These samples represented only those samples from the study in which germinating seedlings were observed. The data for a sample plot consisted of the total number of seedlings of each species that emerged. Differences within an original sample plot were not considered in this analysis. Species counts were log transformed - transformed value $=\ln (y+1)$ - before analysis. Two species were given a zero weight in the analysis, i.e. Cakile constricta and Bulbostylis ciliatifolia, because test runs of the analysis indicated that these species tended to dominate the analysis precluding an interpretable result. In addition, because of the high 
abundance of several, otherwise rare, species in some samples of the seed bank data, rare species were downweighted in the analysis (ter Braak 1988). An analysis of these same plots based upon above-ground species cover from autumn 1990 and spring 1991 was also undertaken. 55 plots were available for this second analysis; cover data were log transformed before analysis, and the downweighting of rare species option was not employed.

To interpret the results of the ordinations, plots were identified according to vegetation types from autumn 1990 in Gibson \& Looney (1992). For both ordinations of the seed bank and above-ground data, the first two ordination axes were retained for interpretation. Spearman rank correlations between sample plot location along ordination axes one and two and plot elevation, distance from $1990 \mathrm{MHW}$, and transect number was calculated using SAS (Anon. 1990b) from data presented by Work et al. (1990). Plot elevation and distance were assigned to classes before analysis, i.e., for elevation $1=0-0.49 \mathrm{~m}$ above datum, $2=0.5-0.99 \mathrm{~m}$, etc., and for distance $1=0-99$, above autumn 1990 MHW, $2=100-199 \mathrm{~m}$, etc. Plots from the dredge spoil below old MHW were assigned a -1 distance class.

\section{Results}

\section{Species richness and density}

Overall, 110 taxa representing $34 \%$ of the known vascular plant flora of Perdido Key were identified as seedlings germinating from the soil seed bank samples
(Table 1). 94 species germinated from autumn 1990 samples and 87 from samples collected in spring 1991. The most abundant single species was Juncus roemerianus (1203 seedlings $/ \mathrm{m}^{2}$ ), followed by Polypremum procumbens (249 seedlings $/ \mathrm{m}^{2}$ ) and Conyza canadensis (130 seedlings $/ \mathrm{m}^{2}$ ). The majority of other species were far less abundant with 22 taxa having a mean abundance of less than one seedling per $\mathrm{m}^{2}$ (App. 1).

The seed bank was dominated by $\mathrm{C}_{3}$ dicots, especially perennials (Table 1 ). There were also many perennial monocots, with a similar number of $\mathrm{C}_{3}$ and $\mathrm{C}_{4}$ species. Annual $\mathrm{C}_{4}$ species were poorly represented, especially $\mathrm{C}_{4}$ annual dicots that were represented by a single species (Chamaesyce ammannioides). There were also only four woody species and a single pteridophyte (Lycopodium sp.). The woody species flora was the most poorly represented of the life forms compared with the known above-ground flora of Perdido Key (four of 43 species; i.e. Baccharis halimifolia, Chrysoma pauciflosculosa, Conradina canescens, and Ilex vomitoria). The other life forms were represented by $20-45 \%$ of the known species, except $\mathrm{C}_{3}$ annual monocots in which six of nine species occurred. The percentage of annual species in the seed bank as a whole varied among vegetation types with early successional vegetation types (strand, dredge spoil, unvegetated) having $44-100 \%$ annual species. The late successional vegetation types (wet and dry swales, wooded dunes, marshes) had a lower range of annual species (25-37\%). As a whole, $29 \%$ of the species from the seed bank were annuals, similar to the $26 \%$ in the known above-ground flora.

The largest number of species germinated from samples originating from wet and dry swales (57 and 54

Table 1. Numbers of species and total density of seedlings germinating from the soil seed bank according to life form and vegetation type. * includes unidentified monocots and + unidentified dicots counted as a single taxa. $n=$ number of plots sampled per vegetation type. ${ }^{\dagger}=$ from Looney et al. (1993), succulents (two species) excluded. Est. = established dunes, Dev. = developed dunes, and Dis. $=$ disturbed dunes.

\begin{tabular}{|c|c|c|c|c|c|c|c|c|c|c|c|c|c|c|}
\hline Life form & Strand & $\begin{array}{l}\text { Wooded } \\
\text { dunes }\end{array}$ & $\begin{array}{l}\text { Back } \\
\text { slopes }\end{array}$ & $\begin{array}{c}\text { Dunes } \\
\text { Est. }\end{array}$ & De. & Dis. & Low & Swales & Wet & Marsh & $\begin{array}{c}\text { Dredge } \\
\text { spoil }\end{array}$ & $\begin{array}{l}\text { Unvege- } \\
\text { tated }\end{array}$ & $\begin{array}{l}\text { Overall } \\
\text { (total) }\end{array}$ & $\begin{array}{l}\text { Above- } \\
\text { ground flora } \\
\text { (total) }\end{array}$ \\
\hline $\mathrm{C}_{3}$ annual monocots & & $2 *$ & $2 *$ & $1 *$ & $1 *$ & $1 *$ & $1 *$ & $3 *$ & $5 *$ & $2 *$ & & 1 & $6^{*}$ & 9 \\
\hline $\mathrm{C}_{3}$ perennial monocots & & 6 & 8 & 1 & & 1 & 3 & 12 & 13 & 5 & 2 & & 17 & 50 \\
\hline $\mathrm{C}_{4}$ annual monocots & & & & & & & & 2 & 1 & & & & 2 & 7 \\
\hline $\mathrm{C}_{4}$ perennial monocots & & 4 & 8 & 4 & 2 & 2 & 8 & 9 & 6 & 4 & 1 & & 15 & 33 \\
\hline $\mathrm{C}_{3}$ annual dicots & 1 & $11^{+}$ & $13^{+}$ & $7^{+}$ & 2 & $7^{+}$ & $7^{+}$ & $14^{+}$ & $10^{+}$ & $6^{+}$ & 4 & 3 & $23^{+}$ & 63 \\
\hline $\mathrm{C}_{4}$ annual dicot & & & 1 & 1 & 1 & 1 & 1 & 1 & & & & & 1 & 4 \\
\hline $\mathrm{C}_{4}$ perennial dicot & & & & & & & & & & & & & & 1 \\
\hline Woody plants & & 4 & 1 & 1 & 1 & & 1 & 2 & 3 & 1 & & & 4 & 43 \\
\hline Pteridophyte & & & & & & & & & 1 & & & & 1 & 5 \\
\hline Total & 1 & 35 & 40 & 17 & 10 & 17 & 27 & 57 & 64 & 32 & 9 & 6 & 110 & 320 \\
\hline$\%$ annual species & 100 & 37 & 40 & 53 & 40 & 53 & 33 & 35 & 25 & 25 & 44 & 50 & 29 & 26 \\
\hline Seedling density (no. $\mathrm{m}^{2}$ ) & 8 & 8987 & 9448 & 4522 & 248 & 5785 & 7975 & 44347 & 22594 & 9702 & 45 & 41 & & \\
\hline
\end{tabular}


species, respectively: Table 1). Wooded dunes, back slopes and marshes also had over 30 species. By contrast, only a single species (Heterotheca subaxillaris) germinated from samples collected from within the strand vegetation type. Nine species germinated from the dredge spoil samples and six species from unvegetated areas.

Seedling densities ranged from $8 / \mathrm{m}^{2}$ in strand samples to $44347 / \mathrm{m}^{2}$ in dry swales (Table 1 ). Seedling densities from developing dunes, dredge spoil and unvegetated areas were also low, whereas densities from wet swales, wooded dunes, back slopes and marshes were comparatively high.

31 of the 35 indicator species for the above-ground vegetation types occurred in the seed bank (App. 1). Four indicator species were not represented in the seed bank; Cladonia spp., Panicum virgatum, Pinus elliotii, and Smilax bona-nox. The abundance of indicator species in the seed bank was related to the vegetation type that the species characterized. The highest density of 19 of 31 indicator species present in the seed bank was from samples collected from the vegetation type that they were designated an indicator species. This is greater than would be expected by chance alone (Fisher's exact test $p=0.0006$ ). For example, Conradina canescens was an indicator species for wooded dunes, and had its highest density in the seed bank in samples collected from this vegetation type (App. 1).

By contrast, Juncus roemerianus was an indicator species of the marsh vegetation type, but germinated at a higher density from samples collected from dry swales. Indicator species from the above-ground vegetation also allowed characterization of the four types of dunes. Eight of 12 indicator species had their highest abundance as seedlings germinating from samples collected from their respective dune vegetation types; more than would be expected by chance alone (Fisher's exact test, $p=0.046)$. Some indicator species were restricted entirely to their vegetation types, e.g. Polygonella polygama was the most abundant of the 35 species germinating from samples collected from wooded dunes, and did not occur in samples from other vegetation types. Other indicator species were widespread in samples from several vegetation types, e.g. Polypremum procumbens occurred in samples collected from wooded dunes for which it was an indicator species, but also occurred in samples from six other vegetation types and unvegetated areas. Two species (Cakile constricta, and Distichlis spicata) germinated from samples other than those for which they were indicator species. Species such as Samolus parviflorus were not indicator species, but nevertheless, germinated with a high density from a single vegetation type.

\section{Similarity of seed bank to above-ground flora}

Jaccard similarities between the seed bank and aboveground floras ranged from a low of zero in the single strand plot (i.e. no species in common) to 0.75 in an established dune plot (Table 2). Overall, the similarity between the seed bank and the above-ground flora was 0.36 , with the mean similarity for each vegetation type ranging from 0.28 to 0.46 (the single sample from the strand was an exception at 0.00 ). There was no significant difference between vegetation types in terms of the similarity between the seed bank and the above-ground flora (ANOVA $F=1.36, p=0.27$, df $=3 / 41$ ). The similarity was significantly different between the season of sampling (autumn 1990 similarity $=0.50$, spring 1991 similarity $=0.30$, ANOVA $F=4.42, p=0.004$, df $=1 / 41$ ) showing that the seed bank flora was more similar to the above-ground flora in the autumn than in the following spring. There was no significant interaction between vegetation type and season (ANOVA $F=$ $0.47, p=0.63$, df = 2/41). Similarly, the seed bank/ above-ground flora similarity coefficients were highly correlated with transect number $\left(r_{s}=-0.25, p=0.07\right)$, but not plot number $\left(r_{s}=0.03, p=0.84\right)$.

\section{Multivariate analysis}

The first two ordination axes revealed that the composition of the seed bank samples was strongly related to the original vegetation type (Fig. 1a) with samples from the dune vegetation subtypes all being assigned low axis one values. The four dune vegetation subtypes were not clearly separated on the ordination (Fig. 1b). Samples from marsh plots and wooded dune plots were assigned axis one values above 200 units. The wooded dune plots were separated from the other plots by the second ordination axis (Fig. 1a). Samples from wet and dry swales were less clearly grouped with respect to the first two ordination axes, nevertheless, they were not assigned axis scores overlapping with the samples from the dune plots. Samples from the dredge spoil were not assigned any particular axis scores and they were located in all areas of the ordination plot (Fig. 1a). Many seed bank samples from autumn 1990 and spring 1991 were assigned similar ordination axis values (Fig. 1c). Nevertheless, some movement of samples through multivariate space between the two dates was apparent. It would appear that some dune plots became more extreme (i.e. spring samples had lower axis one values than autumn samples), and some wooded dune samples were similarly more distinguishable from the location of plots from other vegetation types in the spring than they had been in the preceding autumn (Fig. 1c).

Species scores from the ordination revealed the basis 


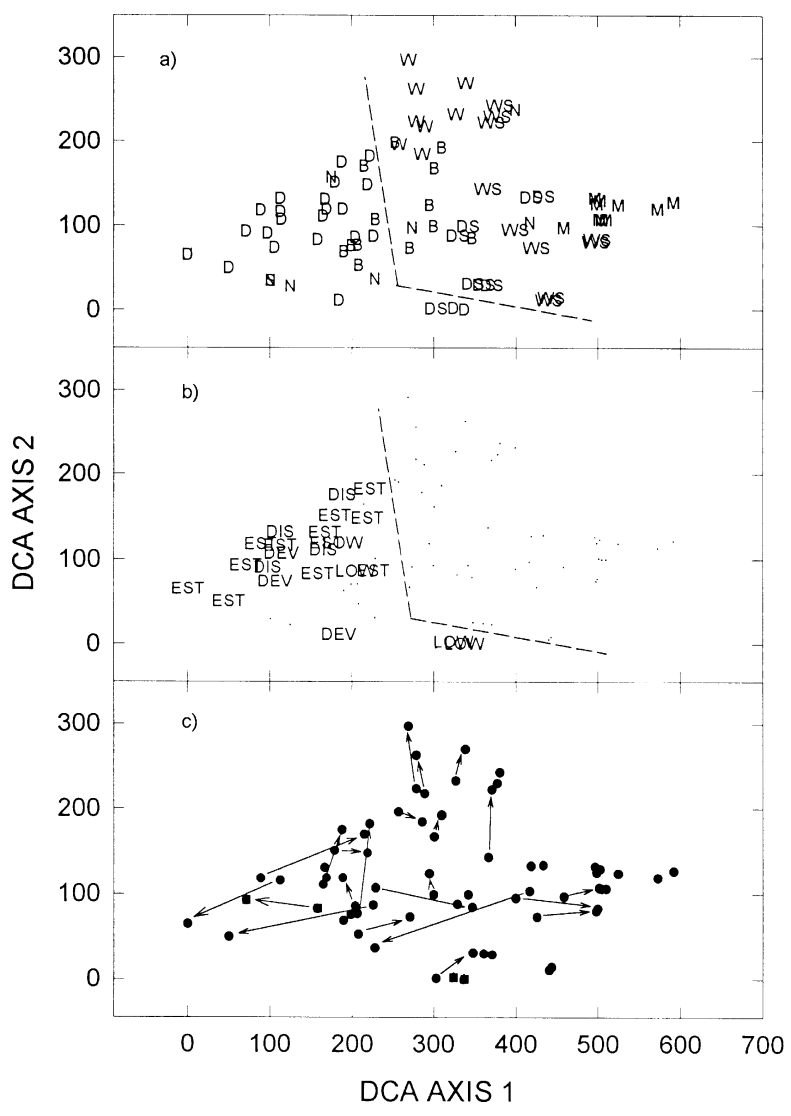

Fig. 1. Ordination of plots based upon seedling density from the soil seed bank: (a) plots labelled according to Autumn 1990 vegetation type (after Gibson \& Looney 1992), B = Back dune; $\mathrm{D}=$ Dune; $\mathrm{DS}=$ Dry swale $\mathrm{M}=$ Marsh; $\mathrm{N}=$ Dredge spoil; $\mathrm{W}=$ Wooded dune; WS = Wet swale; (b) labelled according to Autumn 1990 dune vegetation subtypes (after Gibson $\&$ Looney 1992). Dev = Developing dunes; Dis = Disturbed dunes $;$ Est $=$ Established dunes $;$ Low $=$ Low dunes $; \cdot=$ Nondune plots. The dotted line in (a) and (b) separates plots in the dune vegetation type from plots in other vegetation types; (c) movement of plots in ordination space between samples from autumn 1990 to spring 1991 indicated by arrow. When the pair of plots are less than 20 ordination units apart the arrow is not shown.

for the relationship between plots (Fig. 1). Species typical and characteristic of dune vegetation types, e.g. Oenothera humifusa, Uniola paniculata, Chamaesyce ammannioides, and Heterotheca subaxillaris, were all assigned low axis one scores. By contrast, marsh species such as Juncus roemerianus and Samolus parviflorus were assigned high scores on axis 1 . Species typical of wooded dunes, such as Conradina canescens and Polygonella polygama were assigned high scores on axis 2 . Some species, not considered indicator species of the above-ground vegetation types were nevertheless abundant in the soil seed bank and associated with particular vegetation types. For example, Gratiola hispida is a frequently occurring species of wooded dunes, and was shown to be associated with this vegetation type by virtue of high scores on axis 2 .

Ordination of plots based on above-ground species cover (Fig. 2a) revealed a similar plot to that based upon the seed bank (Fig. 1a), except that axis 1 was reversed. Plots from dune vegetation types were clearly separated from other plots by virtue of high axis one scores (Fig. 2a). A separation of dune vegetation subtypes was apparent, in that plots from developing and disturbed dunes had lower axis two scores than those from established dunes (Fig. 2b). Marsh and wooded dunes were separated by axis two, and dry swales were intermediate between wooded dunes and dunes. Plots from wet swales had scores intermediate between dry swales and wooded dunes. Species scores showed that a similar set of species characterize the separation of plots based upon the above-ground vegetation as that of the seed bank. For example, Oenothera humifusa, Uniola paniculata, Chamaesyce ammannioides and Heterotheca subaxillaris were all assigned high axis one scores reflecting their abundance in the dune vegetation type. Conradina canescens and Polygonella polygama, characteristic of wooded dunes, were assigned low axis one scores. However, additional species, not found in high abundance in the seed bank were associated with the distribution of plots from the various vegetation types based on aboveground species cover. For example, Quercus geminata, a characteristic species of wooded dunes, did not emerge from the soil seed bank, but was assigned low axis two scores on the ordination based upon above-ground cover.

Axis one site scores of the seed bank and aboveground cover ordinations were highly correlated (Spearman Rank Correlation, $r_{s}=-0.81, p<0.0001$, df $=54)$, however axes two were not correlated $(p>0.05)$. Ordination axis one scores from both ordinations were highly correlated with plot elevation (seed bank $r_{s}=$ $-0.46, p<0.0001, \mathrm{df}=82$; above-ground cover, $r_{s}=$ $0.54, p<0.0001, \mathrm{df}=54)$, distance to autumn 1990 MHW (seed bank $r_{c}=0.66, p<0.0001$, above-ground cover, $r_{s}=-0.86, p<0.0001$ ). The seed bank ordination axis one plot scores were correlated with transect number $\left(r_{s}=0.23, p=0.04\right)$, but the correlation between the above-ground cover ordination axis one and transect number was not significant $(p>0.05)$. The soil seed bank second ordination axis plot scores were correlated with distance $\left(r_{s}=-0.29, p<0.007\right)$ and transect number $\left(r_{s}=0.29, p=0.009\right)$. The above-ground cover second ordination axis plot scores were correlated only with elevation $\left(r_{s}=0.34, p=0.01\right)$. 


\section{Discussion}

\section{Seed bank size}

The composition of the germinable soil seed bank on this coastal barrier island varied considerably between vegetation types (Fig. 1, Table 1, App. 1). The highest density of germinable seeds and the greatest number of species was from dry swales, an uncommon vegetation type on the island; only $3.3 \%$ of plots were assigned to this category in autumn 1990 (Gibson \& Looney 1992). Dry swales are low areas with fresh water close to the soil surface and have the highest species richness of all the vegetation types. At the transition between vegetation types that remain drier (e.g. dunes, back slopes) or moister (e.g. wet swales, and marshes), swales (dune slacks of other authors, Ranwell 1972) are a dynamic mosaic of communities that change rapidly in response to alterations in local hydrology (Sykes \& Wilson 1987; Grootjans et al. 1991; Gibson \& Ely 1994). Schat \& Scholten (1985) showed that fluctuations in the soil seed bank of swales reflect species' susceptibility to fluctuating salinity levels. However, in common with swales elsewhere that occur associated with a perched freshwater lens (Zoladeski 1991), the soil moisture of swales on Perdido Key is non-saline. A well-developed seed bank also occurred in wet swales, marsh, back slopes and wooded dunes (App. 1). The density of seedlings from samples collected from the marsh (Table 1) was comparable to other salt-water tidal wetlands (Leck 1989; Ungar \& Woodwell 1993).

By contrast a single species (Heterotheca subaxillaris) germinated at low density from strand samples. $H$. subaxillaris is a species more frequently associated with low and established dunes (Gibson \& Looney 1992). The coastal strand is a dynamic and often transient habitat subject to disturbance from salt water intrusion and sand movement following storms (Davy \& Figueroa 1993). The principal strand species, e.g. Cakile constricta, Oenothera humifusa, Iva imbricata and Hydrocotyle bonariensis were found in the seed bank, but associated principally with the dune vegetation type where they are more abundant in the above-ground vegetation (except Cakile constricta). Presumably, the germinable soil seed bank of the strand is transient reflecting the highly disturbed nature of the substrate.

Few seedlings germinated from the seed bank of unvegetated areas, dredge spoil, and developing dunes (Table 1). Unvegetated areas have a $65 \%$ likelihood of remaining unvegetated in successive years (Gibson \& Ely 1994) and the poorly developed seed bank likely reflects low seed input into the soil. The dredge spoil and developing dunes similarly have low cover and species richness in the above-ground vegetation and

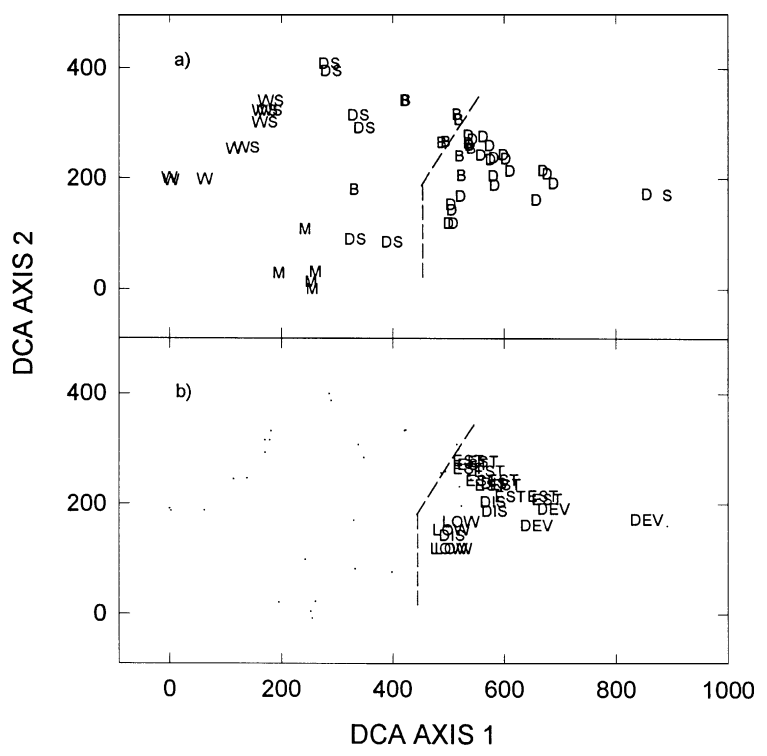

Fig. 2. Ordination of plots based upon cover of species in above-ground vegetation. (a) plots labelled according to $\mathrm{Au}-$ tumn 1990 vegetation type (after Gibson \& Looney 1992), B = Back dunes; $\mathrm{D}=$ Dune; $\mathrm{DS}=$ Dry swale $; \mathrm{M}=$ Marsh; $\mathrm{N}=$ Dredge spoil; $\mathrm{W}=$ Wooded dune; $\mathrm{WS}=$ Wet swale. (b) labelled according to Autumn 1990 dune vegetation subtypes (after Gibson \& Looney 1992). Dev = Developing dunes; Dis $=$ Disturbed dune $;$ Est $=$ Established dunes $;$ Low $=$ Low dunes; - = Non-dune plots. The dotted line in (a) and (b) separates plots in the dune vegetation type from plots in other vegetation types.

likely provide a poor habitat for seed bank development (Looney \& Gibson 1993; Gibson \& Looney 1994). Low plant cover permits high levels of sand movement and seeds deposited by the wind are likely buried or blown away before successful seedling establishment.

\section{Similarity of seed bank to above-ground flora}

The degree of similarity between the seed bank and the above-ground flora was in part a matter of the scale of observation (Figs. 1 and 2, Table 2). At the species scale, the composition of the seed bank resembled the above-ground vegetation in many respects. For example, Juncus roemerianus was the most abundant species germinating from the marsh seed bank samples, and is the dominant plant of these wetlands (Gibson \& Looney 1992). Polygonella polygama, Conradina canescens and other woody species are characteristic of wooded dunes and were abundant in the seed bank from this vegetation type. Hydrocotyle bonariensis is an indicator species for low dunes and its highest density was from the seed bank of this vegetation type. In other cases, the species typical of a vegetation type were not represented 
in the seed bank. For example, Quercus geminata and Q. myrtifolia are characteristic and abundant species of wooded dunes that were absent from the seed bank. Smilax spp. were also notably absent from the seed bank despite their high above-ground abundance in several vegetation types. Several species occurred in the soil seed bank that where previously unknown as part of the flora of Perdido Key, i.e. Gnaphalium falcatum, G. pensilvanicum, G. purpureum, G. spicatum, Anagallis minima, Cyperus compressus, and Fimbristylis autumnalis (Looney et al. 1993). Similarly, Bulbostylis cilatifolia var. coarctata is a rare plant of dry swales that was abundant in the seed bank, but only from this vegetation type. In addition, several species had high abundance in the seed bank of certain vegetation types in which they have a low abundance above-ground and/or a higher abundance in a different vegetation type above-ground; e.g. Juncus roemerianus was the most abundant species in the seed bank from dry swales, yet is the most abundant species above-ground in marshes (Gibson \& Looney 1992). These differences reflect the importance of individual species life histories in determining the extent to which they become incorporated in the seed bank (Thompson 1987; Maun 1994; Zhang \& Maun 1994). In addition, dry swales are often transitional to marshes. Seeds are likely to become dispersed from marshes into swales with overwash during storms where they can remain viable for a long period.

At the community scale of analysis, overall similarity between the seed bank and the above-ground vegetation was 0.36 (Jaccard's index), with no difference between vegetation types, but a higher similarity in the autumn than compared with the following spring (Table 2). This suggests that much of the seed bank was not persistent and that the seed bank became depleted over winter. 19 species were more abundant in the autumn

Table 2. Mean Jaccard similarity coefficients between paired seed bank and above-ground sample plots by vegetation type and dune subgroups (Gibson \& Looney 1992) on Perdido Key.

\begin{tabular}{llrcc}
\hline Vegetation type & Dune subgroup & $n$ & Similarity & SE \\
\hline Strand & & 1 & 0.00 & - \\
Wooded dunes & & 6 & 0.28 & 0.04 \\
Back slopes & & 11 & 0.32 & 0.04 \\
Dunes & 23 & 0.42 & 0.04 \\
& Established & 13 & 0.41 & 0.06 \\
& Developing & 3 & 0.40 & 0.14 \\
& Disturbed & 4 & 0.46 & 0.09 \\
Dry swales & Low & 3 & 0.42 & 0.09 \\
Wet swales & & 4 & 0.34 & 0.06 \\
Marshes & & 5 & 0.39 & 0.02 \\
Overall & & 4 & 0.37 & 0.06 \\
lat & & 54 & 0.36 & 0.05 \\
\hline
\end{tabular}

seed bank than in the following spring, and several more were absent (e.g. Spartina patens, Polygonella gracilis and Muhlenbergia capillaris were absent from spring samples). Ungar \& Woodell (1993) observed that differences between autumn and spring seed bank floras from British salt marshes were due to the presence of fewer annuals in the spring seed bank. In our study, there were fewer annuals germinating in the spring 1991 compared with the autumn 1990 seed bank (25 and 29 species, respectively), but there were also fewer perennials (62 and 65 species, respectively). As in Bertiller's (1992) study of Patagonian grasslands, seed rain during the spring and summer flowering seasons acts to replenish the seed bank before the autumn.

The vegetation types previously identified based on the above-ground vegetation (Gibson \& Looney 1992) were well discriminated in the seed bank, especially dunes, marshes, and wooded dunes (Figs. 1 and 2). The indicator species of these vegetation types were, in 31 of 35 possible cases, present in the seed bank, and in 19 cases were more abundant in the seed bank of the vegetation type than any other. The strong correlation between the first ordination axes of the seed bank and above-ground ordination further attests to the similarity in community and gradient structure between the two strata. This is in contrast to Pierce \& Cowling's (1991a) study of the seed banks of coastal dune vegetation in South Africa in which ordinations of the two strata were different. Considering the clear differences among the above-ground vegetation types, it is perhaps not surprising that the seed bank also reflects the differences between vegetation types. Nevertheless, the different vegetation types are all located within close proximity (average island width is $180-300 \mathrm{~m}$ ) and even short range seed dispersal would likely transport seeds of species from one vegetation type to another (although see Kellman 1974). Such 'contamination' of the seed bank of one vegetation type with species from another is evident in the occurrence of, for example, Cyperus polystachyos a common plant of marsh edges and wet swales, which had its highest seed bank density in samples from low dunes. Marshes and wet swales are successionally older vegetation types than low dunes, so Cyperus polystachyos at least is unlikely to have germinated in the low dune samples from long-lived buried seed that became incorporated when the sample plot was an earlier vegetation type (e.g. Milberg \& Hansson 1994). Indeed, none of the species germinating from the seed bank would fall into this category.

The apparent failure of the seed bank ordination to allow clear discrimination between types of dunes, i.e. established, disturbed, developing and low dunes reflect in part the similarity between these vegetation types as well as their inherent instability. For example, plots 
classified as disturbed, developing and low dunes based upon above-ground vegetation cover were only $25 \%$, $50 \%$ and $33 \%$ likely, respectively, to remain in the same classification a year later (Gibson \& Looney 1992). Established dunes were more stable (80\%), but were still not clearly distinguished from the other dune subtypes in the seed bank ordination (Fig. 1b). Nevertheless, indicator species for the four types of dunes, identified from the above-ground vegetation, were at high density in the seed bank.

Thus, at the scale of vegetation types, the similarity between the seed bank and the above-ground vegetation is poor (although several species may have been missed because of heterogeneous occurrence in the seed bank). This is in accord with many other studies of individual communities or vegetation types (e.g. van der Valk \& Davis 1978; Whipple 1978; Roach 1983). However, at the landscape scale, the seed bank allows an equally clear discrimination of vegetation types (Figs. 1 and 2). This observation has been made from other habitats (e.g. Partridge 1989; although see Pierce \& Cowling 1991a). This suggests that for the coastal dune system studied here, similar factors operate to delineate aboveground communities and seed banks at landscape and local scales, but the details are different at the smaller scale (Matlack \& Good 1990).

\section{Implications for understanding succession and disturbance}

Succession of vegetation on barrier islands such as Perdido Key proceeds towards either wooded dunes or high stable dunes (Cousens 1988; Salter 1993). Early succession vegetation changes rapidly, in contrast to late succession vegetation that exhibits a high degree of compositional stability. For example, a pioneer beach plot on Perdido Key resampled after 10 yr showed only an $8 \%$ similarity (Bray-Curtis similarity) with the original sample, whereas forest and marsh plots exhibited 86 $\%$ and $84 \%$ similarity, respectively, over the same time period (Gibson et al. 1990). Similarly, yearly transitions show that field plots classified as early successional vegetation types, such as strand, have a low probability (0.26) of remaining the same. In contrast, late successional vegetation types, such as wooded dunes, have a high probability (0.94) of remaining the same in subsequent years (Gibson \& Ely 1994). The relationship between successional species replacements and the seed bank of coastal barrier islands has received very little attention (Ehrenfeld 1990). Despite the juxtaposition of habitats on barrier islands, localized dispersal is thought by Ehrenfeld (1990) to permit species, when established, to remain within the appropriate habitat. This would allow the development of the seed bank for those species with seeds which do not all germinate within the year of dispersal.

Swales occur where the ground water is close to the soil surface, and marsh develops on the lagoon side (Ehrenfeld 1990). The seed bank of these low disturbance, late-succession vegetation types was well developed with the exception that the large-seeded woody species (i.e. Quercus spp.) were absent from the wooded dune seed bank. The lower number of species in the tidal marshes was to be expected because of the mix of saline and brackish conditions (Leck 1989). By contrast, a poorly developed and transient seed bank was present in the more frequently disturbed, early successional dredge spoil, unvegetated areas and strand. These vegetation types also had the lowest percentage of annual species. The dune and back slope seed banks were also poor for most species, again suggesting a transient seed bank. Pierce \& Cowling (1991b) found the seed banks of dune fynbos for six shrubs to be largely transient and unreliable in not ensuring direct replacement following disturbance. These contrasts support a general pattern of increasing seed bank development and a persistent rather than transient seed bank with decreasing frequency and increasing time since disturbance (extensive sand movement, salt spray) and successional maturity (Ehrenfeld 1990). Although these patterns are consistent with the known dynamics of our study site and coastal barrier islands, the results are inconsistent with Planisek \& Pippen's (1984) study of four vegetation types on Lake Michigan dunes in which no seeds germinated even from dune swale samples. Moreover, the results presented here are inconsistent with Thompson's (1978) prediction that seed bank size (based here upon number of germinating seedlings and species richness) should decrease with increasing successional age and decreasing disturbance. Pierce \& Cowling (1991a) were also unable to support Thompson's prediction in their study of coastal dune vegetation as were other studies from different habitats (e.g. tropical forest; Rico-Gray \& García-Franco 1992). By contrast, Oosting \& Humphreys (1940), Livingston \& Allessio (1968), Donelan \& Thompson (1980) and Roberts \& Vankat (1991) found species richness and/or seedling density of the seed bank from old field-to-forest seres to decrease. Roberts \& Vankat (1991) also observed a predicted decrease in the number of annual species in the seed bank of an old field-forest succession; this pattern was not found in the present study. This discrepancy in patterns of seed bank development between studies likely reflects intrinsic differences between the successional and disturbance regimes of the habitats concerned as well as site specific factors. It may also reflect fundamental differences between primary succession where the seed bank is starting from zero (this report; Nakashizuka et al. 1993), and 
secondary succession where a disturbed, but viable seed bank is present (Oosting \& Humphreys 1940; Livingston \& Allessio 1968; Thompson 1978; Donelan \& Thompson 1980; Levassor et al. 1990; Roberts \& Vankat 1991). Generalizations about seed bank development should take account of the type of seed bank and the nature of the successional sequence of which it is a part.

Acknowledgements. Support for this study was provided to the University of West Florida by the National Park Service. Ted Simons and Carl Zimmerman facilitated many logistic arrangements. James Burkhalter helped with seedling identifications, Ron Hill undertook some preliminary data analysis, and Diana Athnos, Debbie Looney, Michelle Misner, Robin McCall, and Misty Nabers helped in the field. Beth Middleton and Joe Ely provided critical comments on a draft of the manuscript.

\section{References}

Anon. 1990a. SAS/STAT User's Guide, Version 6, 4th ed., Volume 1. SAS Institute Inc. Cary, NC.

Anon. 1990b. SAS Procedures Guide, Version 6, 3rded., SAS Institute Inc. Cary, NC.

Anderberg, M.R. 1973. Cluster Analysis for Applications. Academic Press, Inc., New York, NY.

Bertiller, M.B. 1992. Seasonal variation in the seed bank of a Patagonian grassland in relation to grazing and topography. J. Veg. Sci. 3: 47-54.

Boorman, J. M. \& Fuller, R.M. 1984. The comparative ecology of two sand dune biennials: Lactuca virosa L. and Cynoglossum officinale L. New Phytol. 69: 609-629.

Cousens, M.I. 1988. Phytosociology and hurricane initiated revegetation on Perdido Key, Gulf Island National Seashore. Final Report to the U.S. Department of the Interior, National Park Service, Atlanta, GA.

Daubenmire, R. 1959. A canopy-coverage method of vegetational analysis. Northwest Sci. 33: 43-66.

Davy, A.J. \& Figueroa, M.E. 1993. The colonization of strandlines. In: Miles, J. \& Walton, D.W.H. (eds.) Primary Succession on Land, pp. 113-132. Blackwell, London.

Dolan, R. \& Lins, H. 1987. Beaches and barrier islands. Sci. Amer. 255: 68-77.

Donelan, M. \& Thompson, K. 1980. Distribution of buried viable seeds along a successional series. Biol. Conserv. 17: 297-311.

Ehrenfeld, J.G. 1990. Dynamics and processes of barrier island vegetation. Rev. Aquat. Sci. 2: 437-480.

Gibson, D.J. \& Ely, J.S. 1994. Vegetation monitoring after beach nourishment on Perdido Key. Final Report submitted to the National Park Service. Institute for Coastal \& Estuarine Research. Research Paper Series ICER Rep. 02:09-22-94, University of West Florida, Pensacola, FL.

Gibson, D.J. \& Looney, P.B. 1992. Seasonal variation in vegetation classification on Perdido Key, a barrier island off the coast of the Florida panhandle. J. Coast. Res. 8: 943-956.
Gibson, D.J. \& Looney, P.B. 1994. Vegetation colonization of dredge spoil on Perdido Key, Florida. J. Coast. Res. 10: 133-143.

Gibson, D.J., Ely, J.S., Looney, P.B. \& Gibson, P.T. 1995. Effects of inundation from the storm surge of Hurricane Andrew upon primary succession on dredge spoil. J. Coast. Res. Spec. Iss. 21: 208-216.

Gibson, D.J., Looney, P.B. \& Cousens, M.I. 1990. Succession in coastal barrier island communities over a ten-year period. Bull. Ecol. Soc. Am. 71 (Suppl.): 165.

Goodall, D.W. 1973. Sample similarity and species correlation. In: Whittaker, R.H. (ed.) Ordination and Classification of Communities, pp. 105-156. Junk, The Hague.

Grootjans, A.P., Hartog, P.S., Fresco, L.F.M. \& Esselink, P.H. 1991. Succession and fluctuation in a wet dune slack in relation to hydrological changes. J. Veg. Sci. 2: 545-554.

Gross, K.L. 1990. A comparison of methods for estimating seed numbers in the soil. J. Ecol. 78: 1079-1093.

Hill, M.O. \& Gauch, H.G. 1980. Detrended correspondence analysis, an improved ordination technique. Vegetatio 42 : 47-58.

Keddy, P.A., Wisheu, I.C., Shipley, B. \& Gaudet, C. 1989. Seed banks and vegetation management for conservation: toward predictive community ecology. In: Leck, M.A., Parker, V.T. \& Simpson, R.L. (eds.) Ecology of Soil Seed Banks, pp. 347-363. Academic Press, San Diego, CA.

Kellman, M. 1974. Preliminary seed budgets for two plant communities in coastal British Columbia. J. Biogeogr. 1: 123-133.

Leck, M.A. 1989. Wetland seed banks. In: Leck, M.A., Parker, V.T. \& Simpson, R.L. (eds.) Ecology of Soil Seed Banks, pp. 283-305. Academic Press, San Diego, CA.

Levassor, C., Ortega, M. \& Peco, B. 1990. Seed bank dynamics of Mediterranean pastures subjected to mechanical disturbance. J. Veg. Sci. 1: 339-334.

Livingston, R.B. \& Allessio, M.L. 1968. Buried viable seed in successional field and forest stands, Harvard Forest, Massachusetts. Bull. Torrey Bot. Club 95: 58-69.

Looney, P. B. \& Gibson, D.J. 1993. Vegetation monitoring of beach nourishment. In: Stauble, D.K. \& Kraus, N.C. (eds.) Beach Nourishment Engineering and Management Considerations, pp. 226-241. Coastlines of the World, American Society of Civil Engineers, New York, NY.

Looney, P.B., Gibson, D.J., Blyth, A. \& Cousens, M.I. 1993. Flora of the Gulf Islands National Seashore, Perdido Key, Florida. Bull. Torrey Bot. Club 120: 327-341.

Ludwig, J.A. \& Reynolds, J.F. 1988. Statistical Ecology. Wiley Interscience, New York, NY.

Mack, R.N. 1976. Survivorship of Cerastium atrovirens at Aberffraw, Anglesey. J. Ecol. 64: 309-312.

Matlack, G.R. \& Good, R.E. 1990. Spatial heterogeneity in the soil seed bank of a mature Coastal Plain forest. Bull. Torrey Bot. Club 117: 143-152.

Maun, M.A. 1994. Adaptations enhancing survival and establishment of seedlings on coastal dune systems. Vegetatio 111: 59-70.

Milberg, P. \& Hansson, M.L. 1994. Soil seed bank and species turnover in a limestone grassland. J. Veg. Sci. 5: 35-42.

Nakashizuka, T., Iida, S., Suzuki, W. \& Tanimoto, T. 1993. Seed dispersal and vegetation development on a debris 
avalanche on the Ontake volcano, Central Japan. J. Veg. Sci. 4: 537-542.

Oosting, H.J. \& Humphreys, M.E. 1940. Buried viable seeds in a successional series of old field and forest soils. Bull. Torrey Bot. Club 67: 253-273.

Palik, T.F. \& Kunneke, J.T. 1984. Northwestern Florida Ecological Characterization: An Ecological Atlas. Map Narratives. U.S. Department of the Interior, Fish and Wildlife Service, FWS/OBS-82/47.1. Minerals Management Service 85-0011, Washington, DC.

Partridge, T.R. 1989. Soil seed banks of secondary vegetation on the Port Hills and Banks Penninsula, Canterbury, New Zealand, and their role in succession. N. Z. J. Bot. 27: 421436.

Peart, D.R. 1989. Species interactions in a successional grassland. I. Seed rain and seedling recruitment. J. Ecol. 77: 236-251.

Pemadasa, M.A. \& Lovell, P.H. 1975. Factors controlling germination of some dune annuals. J. Ecol. 63: 41-59.

Pierce, S.M. \& Cowling, R.M. 1991a. Disturbance regimes as determinants of seed banks in coastal dune vegetation of the southeastern Cape. J. Veg. Sci. 2: 403-412.

Pierce, S.M. \& Cowling, R.M. 1991b. Dynamics of soil-stored seed banks of six shrubs in fire-prone dune fynbos. J. Ecol. 79: 731-747.

Plansiek, S.L. \& Pippen, R.W. 1984. Do sand dunes have seed banks? Mich. Bot. 23: 169-177.

Ranwell, D.S. 1972. Ecology of Salt Marshes and Sand Dunes. Chapman \& Hall, London.

Rico-Gray, V. \& García-Franco, J.G. 1992. Vegetation and soil seed bank of successional stages in tropical lowland deciduous forest. J. Veg. Sci. 3: 617-624.

Roach, D.A. 1983. Buried seed and stranding vegetation in two adjacent tundra habitats, northern Alaska. Oecologia (Berl.) 60: 359-364.

Roberts, T.L. \& Vankat, J.L. 1991. Floristics of a chronosequence corresponding to old field-deciduous forest succession in southwestern Ohio. II. Seed banks. Bull. Torrey Bot. Club 118: 377-385.

Rothrock, P.E., Squiers, E.R. \& Sheeley, S. 1993. Heterogeneity and size of a persistent seed bank of Ambrosia artemisiifolia L. and Setaria faberi Herrm. Bull. Torrey Bot. Club 120: 417-422.

Schat, H. \& Scholten, M. 1985. Comparative population ecology of dune slack species: the relation between population stability and germination behaviour in brackish environments. Vegetatio 61: 189-195.

Stalter, R. 1993. Dry coastal ecosystems of the Gulf coast of the United States of America. In: van der Maarel, E. (ed.) Dry Coastal Ecosystems, Africa, America, Asia and Oceania. Ecosystems of the World 2B, pp. 375-387. Elsevier, Amsterdam.

Stone, G.W. \& Morgan, J. 1993. Implications for a constant rate of relative sea-level rise during the last Millennium along the Northern Gulf of Mexico: Santa Rosa Island, Florida. Shore \& Beach 61: 24-27.

Stone, G.W. \& Salmon, J.D. 1988. Hurricane-related morphodynamics and implications for hazard mitigation, Perdido Key, Florida, U.S.A. Coast. Manage. 16: 245-270.

Sykes, M.T. \& Wilson, J.B. 1987. The vegetation of a New
Zealand dune slack. Vegetatio 71: 13-19.

ter Braak, C.J.F. 1988. CANOCO - a FORTRAN program for canonical community ordination by [partial] [detrended] [canonical] correspondence analysis, principal components analysis and redundancy analysis (version 2.1). Agricultural Mathematics Group, Technical Report LWA88-02, Wageningen.

Thompson, K. 1978. The occurrence of buried viable seeds in relation to environmental gradients. J. Biogeogr. 5: 425430.

Thompson, K. 1987. Seeds and seed banks. New Phytol. 106 (Suppl.): 23-34.

Thompson, K. \& Grime, J.P. 1979. Seasonal variation in the seed banks of herbaceous species in ten contrasting habitats. J. Ecol. 67: 893-922.

Ungar, I.A. \& Woodell, S.R.J. 1993. The relationship between the seed bank and species composition of plant communities in two British salt marshes. J. Veg. Sci. 4: 531-536.

van der Valk, A.G. \& Davis, C.B. 1978. The role of seed banks in the vegetation dynamics of prairie glacial marshes. Ecology 59: 322-335.

Warr, S.J., Kent, M. \& Thompson, K. 1994. Seed bank composition and variability in five woodlands in south-west England. J. Biogeogr. 21: 151-168.

Watkinson, A.R. 1978. The demography of a sand dune annual: Vulpia fasciculata. II. The dynamics of seed populations. J. Ecol. 66: 35-44.

Whipple, S.A. 1978. The relationship of buried, germinating seeds to vegetation in an old-growth Colorado subalpine forest. Can. J. Bot. 56: 1505-1509.

Work, P., Charles, L. \& Dean, R.G. 1991. Perdido Key Historical Summary and Interpretation of Monitoring Programs. Coastal \& Engineering Dept., Gainesville, FL.

Work, P., Lin, L.-H. \& Dean, R.G. 1990. Perdido Key Beach Nourishment Project: Gulf Islands National Seashore. Pre-Nourishment Survey - Conducted Oct. 28 -Nov. 3, 1989. Coastal and Oceanographic Eng. Dept., University of Florida, Gainesville, FL.

Zhang, J. \& Maun, M.A. 1994. Potential for seed bank formation in seven Great Lakes sand dune species. Am. J. Bot. 81: 387-394.

Zoladeski, C.A. 1991. Vegetation zonation in dune slacks on the Òeba Bar, Polish Baltic Sea coast. J. Veg. Sci. 2: 255258
Received 6 February 1995; Revision received 31 July 1995; Accepted 8 August 1995.

For App. 1, see p. 836. 
App. 1. Density of seedlings germinating (no. per $\mathrm{m}^{2}$ ) from seed bank samples according to vegetation type. Only species with a mean density of $>25 / \mathrm{m}^{2}$ or identified as an indicator species for a vegetation type (in bold) (Gibson \& Looney 1992) are reported. A complete listing is available from the authors. Unveg = unvegetated plots. Life form types: $\mathrm{C}_{3} \mathrm{AM}=\mathrm{C}_{3}$ annual monocot; $\mathrm{C}_{3} \mathrm{PM}$ $=\mathrm{C}_{3}$ perennial monocot; $\mathrm{C}_{4} \mathrm{PM}=\mathrm{C}_{4}$ perennial monocot; $\mathrm{C}_{3} \mathrm{AD}=\mathrm{C}_{3}$ annual dicot; $\mathrm{C}_{3} \mathrm{PD}=\mathrm{C}_{3}$ perennial dicot; $\mathrm{C}_{4} \mathrm{AD}=\mathrm{C}_{4}$ annual dicot; $\mathrm{W}=$ woody plant.

\begin{tabular}{|c|c|c|c|c|c|c|c|c|c|c|c|c|c|c|}
\hline \multirow[t]{2}{*}{ Species } & \multirow{2}{*}{$\begin{array}{l}\text { Life } \\
\text { form }\end{array}$} & \multirow[t]{2}{*}{ Strand } & \multirow{2}{*}{$\begin{array}{l}\text { Wood } \\
\text { dunes }\end{array}$} & \multirow{2}{*}{$\begin{array}{c}\text { Back } \\
\text { slopes }\end{array}$} & \multicolumn{4}{|c|}{ Dunes } & \multicolumn{2}{|c|}{ Swales } & \multirow{2}{*}{$\begin{array}{c}\text { Marsh } \\
\text { spoil }\end{array}$} & \multirow[t]{2}{*}{ Dredge } & \multirow[t]{2}{*}{ Unveg } & \multirow{2}{*}{$\begin{array}{r}\text { Overall } \\
\text { mean }\end{array}$} \\
\hline & & & & & Est. & Dev. & Dis. & Low & Dry & Wet & & & & \\
\hline Andropogon virginicus var. virginicus & $\mathrm{C}_{4} \mathrm{PM}$ & 0 & 16 & 28 & 3 & 0 & 0 & 0 & 269 & 91 & 0 & 0 & 0 & 27 \\
\hline Balduina angustifolia & $\mathrm{C}_{3} \mathrm{AD}$ & 0 & 5 & 0 & 0 & 0 & 0 & 0 & 0 & 0 & 0 & 0 & 0 & $<1$ \\
\hline Bulbostylis ciliatifolia var. coarctata & $\mathrm{C}_{3} \mathrm{AM}$ & 0 & 0 & 0 & 0 & 0 & 0 & 0 & 0 & 380 & 0 & 0 & 3 & 27 \\
\hline Cakile constricta & $\mathrm{C}_{3} \mathrm{AD}$ & $\mathbf{0}$ & 0 & 0 & 0 & 12 & 0 & 0 & 0 & 0 & 0 & 4 & 3 & 2 \\
\hline Centella asiatica & $\mathrm{C}_{3} \mathrm{PD}$ & 0 & 0 & 0 & 0 & 0 & 0 & 10 & 21 & 79 & 12 & 0 & 0 & 9 \\
\hline Chrysopsis godfreyi & $\mathrm{C}_{3} \mathrm{PD}$ & 0 & 0 & 826 & $\mathbf{0}$ & 0 & 41 & 0 & 5 & 0 & 0 & 0 & 0 & 79 \\
\hline C. godfreyi fo. viridis & $\mathrm{C}_{3} \mathrm{PD}$ & 0 & 0 & 31 & 0 & 0 & 0 & 0 & 5 & 0 & 0 & 2 & 0 & 4 \\
\hline Chrysoma pauciflosculosa & W & 0 & 5 & 0 & $\mathbf{0}$ & 0 & 0 & 0 & 0 & 0 & 0 & 0 & 0 & $<1$ \\
\hline Conradina canescens & $\mathrm{W}$ & 0 & 475 & 0 & 3 & 0 & 0 & 0 & 5 & 58 & 0 & 0 & 0 & 34 \\
\hline Conyza canadensis var. pusilla & $\mathrm{C}_{3} \mathrm{AD}$ & 0 & 16 & 34 & 6 & 0 & 1947 & 145 & 0 & 4 & 0 & 0 & 0 & 129 \\
\hline Cyperus lecontei & $\mathrm{C}_{3} \mathrm{PM}$ & 0 & 36 & 293 & 8 & 0 & 0 & 10 & 31 & 157 & 0 & 0 & 0 & 45 \\
\hline C. polystachyos & $\mathrm{C}_{4} \mathrm{PM}$ & 0 & 5 & 0 & 6 & 4 & 0 & 1591 & 300 & 8 & 29 & 0 & 0 & 72 \\
\hline Cyperus sp. & - & 0 & 5 & 45 & 0 & 0 & 0 & 0 & 98 & 1037 & 4 & 0 & 0 & 91 \\
\hline Erechtites hieracifolia & $\mathrm{C}_{3} \mathrm{AD}$ & 0 & 0 & 3 & 0 & 0 & 0 & 0 & 108 & 21 & 37 & 0 & 0 & 11 \\
\hline Fimbristylis caroliniana & $\mathrm{C}_{4} \mathrm{PM}$ & 0 & 0 & 28 & 0 & 0 & 0 & 41 & 201 & 45 & 4 & 0 & 0 & 20 \\
\hline F. castanea & $\mathrm{C}_{3} \mathrm{PM}$ & 0 & 0 & 0 & 0 & 0 & 0 & 72 & 0 & 504 & 252 & 0 & 0 & 60 \\
\hline Fuirena scirpoidea & $\mathrm{C}_{3} \mathrm{PM}$ & 0 & 10 & 65 & 0 & 0 & 0 & 0 & 289 & 322 & 0 & 0 & 0 & 49 \\
\hline Gratiola hispida & $\mathrm{C}_{3} \mathrm{PD}$ & 0 & 331 & 0 & 0 & 0 & 0 & 0 & 0 & 95 & 0 & 0 & 0 & 28 \\
\hline Heterotheca subaxillaris & $\mathrm{C}_{3} \mathrm{AD}$ & 4 & 0 & 4 & 269 & 12 & 263 & 62 & 0 & 0 & 0 & 2 & 6 & 69 \\
\hline Hydrocotyle bonariensis & $\mathrm{C}_{3} \mathrm{PD}$ & 0 & 0 & 0 & 0 & 0 & 5 & 145 & 36 & 12 & 0 & 0 & 0 & 8 \\
\hline Ilex vomitoria & W & 0 & 10 & 0 & 0 & 0 & 0 & 0 & 0 & 8 & 0 & 0 & 0 & 1 \\
\hline Iva imbricata & $\mathrm{C}_{3} \mathrm{PD}$ & $\mathbf{0}$ & 0 & 0 & 0 & 4 & 98 & 10 & 0 & 0 & 0 & 0 & 0 & 7 \\
\hline Juncus roemerianus & $\mathrm{C}_{3} \mathrm{PM}$ & 0 & 0 & 0 & 0 & 0 & 0 & 0 & 16321 & 256 & 2318 & 2 & 0 & 1203 \\
\hline J. scirpoides & $\mathrm{C}_{3} \mathrm{PD}$ & 0 & 150 & 45 & 0 & 0 & 5 & 0 & 181 & 822 & 0 & 1 & 0 & 88 \\
\hline Lachnocaulon engleri & $\mathrm{C}_{3} \mathrm{PD}$ & 0 & 191 & 0 & 0 & 0 & 0 & 0 & 0 & 248 & 0 & 0 & 0 & 31 \\
\hline Linaria floridana & $\mathrm{C}_{3} \mathrm{AD}$ & 0 & 36 & 420 & 437 & 0 & 72 & 341 & 10 & 240 & 0 & 0 & 0 & 122 \\
\hline Ludwigia sp. & $\mathrm{C}_{3} \mathrm{PD}$ & 0 & 0 & 0 & 0 & 0 & 0 & 0 & 0 & 673 & 4 & 0 & 0 & 52 \\
\hline Muhlenbergia capillaris & $\mathrm{C}_{3} \mathrm{PM}$ & 0 & 0 & 0 & 0 & 0 & 0 & 0 & 26 & 12 & 0 & 0 & 0 & 3 \\
\hline Oenothera humifusa & $\mathrm{C}_{3} \mathrm{PD}$ & 0 & 0 & 7 & 74 & 41 & 52 & 103 & 0 & 0 & 0 & 0 & 3 & 18 \\
\hline Panicum amarum var. amarum & $\mathrm{C}_{4} \mathrm{PM}$ & 0 & 0 & 7 & 0 & 0 & $\mathbf{0}$ & 10 & 0 & 0 & 0 & 0 & 0 & 1 \\
\hline P. polygama & $\mathrm{C}_{3} \mathrm{PD}$ & 0 & 454 & 0 & 0 & 0 & 0 & 0 & 0 & 0 & 0 & 0 & 0 & 28 \\
\hline Polypremum procumbens & $\mathrm{C}_{3} \mathrm{AD}$ & 0 & 491 & 1295 & 68 & 0 & 5 & 114 & 997 & 343 & 0 & 0 & 3 & 249 \\
\hline Sabatia stellaris & $\mathrm{C}_{3} \mathrm{AD}$ & 0 & 5 & 0 & 0 & 0 & 0 & 0 & 253 & 165 & 145 & 0 & 0 & 40 \\
\hline Samolus parviflorus & $\mathrm{C}_{3} \mathrm{PD}$ & 0 & 0 & 0 & 0 & 0 & 0 & 0 & 0 & 0 & 802 & 0 & 0 & 62 \\
\hline Schizachyrium maritimum & $\mathrm{C}_{4} \mathrm{PM}$ & 0 & 0 & 58 & 32 & 0 & 57 & 207 & 5 & 0 & 0 & 1 & 0 & 19 \\
\hline Spartina patens & $\mathrm{C}_{4}^{4} \mathrm{PM}$ & 0 & 0 & 0 & 0 & 0 & 0 & 41 & 21 & 4 & 4 & 0 & 0 & 3 \\
\hline Stipulicida setacea & $\mathrm{C}_{3} \mathrm{AD}$ & 0 & 31 & 79 & 708 & 0 & 36 & 10 & 103 & 91 & 0 & 4 & 0 & 102 \\
\hline Strophostyles helvola & $\mathrm{C}_{3} \mathrm{AD}$ & 0 & 0 & 0 & 0 & 0 & 0 & 31 & 16 & 0 & 0 & 0 & 0 & 2 \\
\hline Uniola paniculata & $\mathrm{C}_{4} \mathrm{PM}$ & 0 & 0 & 3 & 148 & 29 & 16 & 0 & 0 & 0 & 0 & 0 & 0 & 20 \\
\hline Utricularia subulata & $\mathrm{C}_{3} \mathrm{PD}$ & 0 & 0 & 0 & 0 & 0 & 0 & 0 & 0 & 1140 & 0 & 0 & 0 & 88 \\
\hline Xyris sp. & $\mathrm{C}_{3} \mathrm{PD}$ & 0 & 222 & 0 & 0 & 0 & 0 & 0 & 5 & 946 & 0 & 0 & 0 & 87 \\
\hline Unidentified dicots & - & 0 & 387 & 454 & 354 & 0 & 238 & 145 & 315 & 252 & 351 & 6 & 0 & 190 \\
\hline Unidentified monocots & - & 0 & 267 & 179 & 18 & 4 & 16 & 124 & 708 & 595 & 207 & 0 & 0 & 145 \\
\hline
\end{tabular}

